\title{
RESEARCH IN RAKE TINES WEAR
}

\author{
Jan Kaminski, Michal Sypula, Jaroslaw Chlebowski, Tomasz Nowakowski \\ Warsaw University of Life Sciences, Poland \\ jan_kaminski@sggw.pl,michal_sypula@sggw.pl,jaroslaw_chlebowski@sggw.pl, \\ tomasz_nowakowski@sggw.pl
}

\begin{abstract}
Before going of the machine into exploitation, the measurements of the new tines welded to the drum rakes were performed. After collecting rocks from the surfaces of 102 ha and 222 ha, the measurements of the worn tines welded to the drum rakes were performed. Differences in dimensions of the individual tines after wear in two phases were determined. Volumetric and mass wear of the tines were specified. The percentage loss of tine mass due to abrasion was calculated. Mass index of tines wear, expressed in $\mathrm{mg} \cdot \mathrm{ha}^{-1}$, taking into account the treated surface, was calculated. Mass index of tine wear, expressed in $\mathrm{mg} \cdot \mathrm{km}^{-1}$ in terms of the path travelled by tine, was calculated. The degree wear of tines with a thickness of $20 \mathrm{~mm}$ depended on the type of steel of which the tines were made. In the long term exploitation, tines made of Hardox steel were characterized by the highest average consumption of $158 \mathrm{mg} \cdot \mathrm{km}^{-1}$, and differences in the consumption of tines made of Hadfield and boron steel were insignificant and amounted to $131 \mathrm{mg} \cdot \mathrm{km}^{-1}$ and $130 \mathrm{mg} \cdot \mathrm{km}^{-1}$, respectively. The tines of smaller cross-section (thickness of $16 \mathrm{~mm}$ ), made of the same boron steel were worn more intensively than the tines of greater thickness $(20 \mathrm{~mm})$, and the average values of the indicators were amounted to $152 \mathrm{mg} \cdot \mathrm{km}^{-1}$ and $130 \mathrm{mg} \cdot \mathrm{km}^{-1}$, respectively. Tines made of Hardox steel were characterized by the biggest non-uniformity of wear. The standard deviations from the mean value of tine wear after the second stage did not exceed $18.4 \%$ for Hardox steel, $16.0 \%$ for Hadfield steel and $13.0 \%$ for boron steel.
\end{abstract}

Keywords: volumetric wear, mass wear, wear indicator.

\section{Introduction}

The working elements of agricultural tools, moving in the soil, wear out mainly as a result of the impact of hard soil particles on their surfaces (some of the elements are exposed to overload caused by hitting stones) [1]. Miller [2] reported that the presence of stones over $15 \mathrm{~mm}$ in diameter in the amount of $0.05 \%$ increased the wear rate by 25 times comparing to clay soils free of stones. Stones with dimensions above $30 \mathrm{~mm}$ are usually considered undesirable and eligible to be removed from the fields. However, smaller stones than 20 to $30 \mathrm{~mm}$ can also threaten crop machines. The scale of their occurrence and the size of damage caused by them are much smaller than the damage caused by larger stones. The technical possibilities of removing small stones of diameter up to $30 \mathrm{~mm}$ are limited, because of the difficulty in separating small stones from the ground [3].

The wear of parts of machines working in soil is not unambiguous, because the values of this parameter depend on the intensity of changes in the geometry of the working elements, and this, in turn, is related to the operating conditions. Elements and tools of these machines are subjected to very high mechanical loads, intensive abrasion caused by hard components of soil (mainly $\mathrm{SiO}_{2}$ ), aggressive plant protection agents, natural fertilizers and chemical fertilizers [4].

Therefore, the selection of appropriate construction materials in the construction of agricultural machinery is extremely important, but also very difficult. Among the modern construction materials used for elements of machines and equipment for soil treatment, wear-resistant steels are used; boron steels; multilayer welds overlay based on transition metals and amphoteric elements; sintered carbides [5].

Steels with boron addition (Hardox 450 and boron B27) boride by laser are characterized by greater resistance to friction wear, better cohesion of the coating and less brittleness than diffusive boronizing. Hardox 450 steel due to its chemical composition (lower carbon content) and the condition of the ground (tempered martensite) has more favorable properties than boron steel after laser boronizing: greater micro-hardness and resistance to wear caused by friction [6]. Hadfield steel has an austenitic structure and is characterized by the hardening of its surface during abrasion and crumbling, as well as good ductility parameters, impact resistance and the ability to overcome dynamic loads [7].

The most reliable assessment of the wear of the used working element is obtained in the real conditions that are widely variable. Variable parameters can be: soil parameters, including the soil composition, moisture content, degree of compaction, stones and gravel content, $\mathrm{pH}$ and operating parameters, i.e. the working speed and working depth. These factors determine the processes occurring 
in the tribological pair of material of the working element and soil, affecting the geometry of wear and thus the durability of the element [8].

The purpose of this work was to determine the wear of tines on the length of the shaft of the stone rake and the degree of tines wear for selected types of abrasion resistant steels (Hardox 450, Hadfield $\mathrm{X} 120 \mathrm{Mn} 12$, boron B27).

\section{Materials and methods}

Research of the degree of tines wear was carried out during the exploitation of the stone rake in light stony soil. The tines wear was determined in 2 stages: after processing the area of 102 and 222 ha. The given working speed during stone collection was $2.5 \mathrm{~km} \cdot \mathrm{h}^{-1}$. The shaft with tines was positioned at an angle of $63^{\circ}$ in relation to the movement direction. The depth of tines work was 70 $\mathrm{mm}$ and the width of the rake was $2.5 \mathrm{~m}$. The average soil moisture content in the layer up to $10 \mathrm{~cm}$ was $12.6 \%$ and the compactness and volume density were $580 \mathrm{kPa}$ and $1.52 \mathrm{~g} \cdot \mathrm{cm}^{-3}$, respectively. The stony fields were varied and amounted to $15.3 \pm 4.7 \mathrm{t} \cdot \mathrm{h}^{-1}$.

In the tests of abrasion resistance of elements working in soil, mass wear and linear wear indicators were used $[9 ; 10]$.

The indicator of mass wear of the stone rake shaft is related to the path travelled by the tine and is expressed in $\mathrm{mg} \cdot \mathrm{km}^{-1}$. In the literature, it is also given in relation to the treated area in $\mathrm{g} \cdot \mathrm{ha}^{-1}$. This study investigated the influence of welding places (positioning) of tines for their wear in accordance to Figure 1.

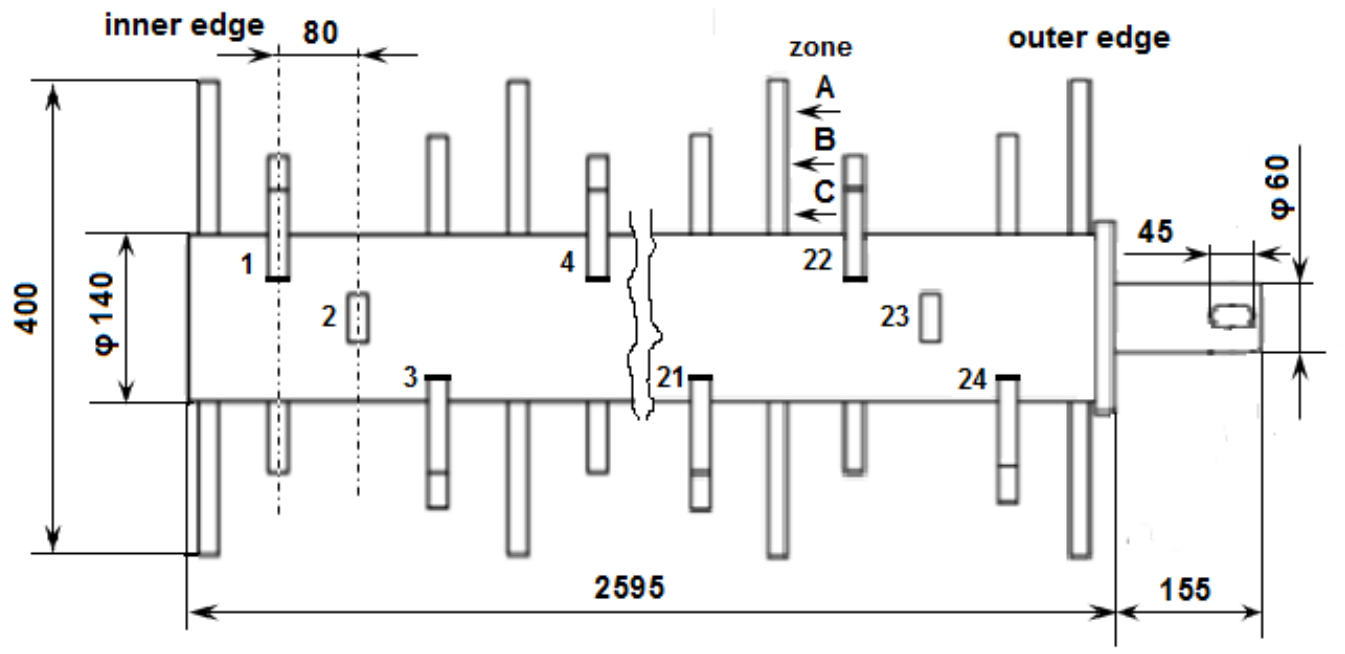

Fig. 1. Basic dimensions of rake shaft and position of tines

Tests were carried out for tines made of Hardox 450, Hadfield X120Mn12 and boron B27 steels. The dimensions of tines welded to the shafts worn-up during the machine operation were measured. Tines were numbered from the outer edge of the rotor in the order from 1 to 24 (Fig. 1). The rotor tines from 1 to 9 had a cross-section of $20 \mathrm{~mm}$ x $40 \mathrm{~mm}$, while tines from 10 to 24 had a nominal cross-section of $16 \mathrm{~mm}$ x $40 \mathrm{~mm}$. The measurements were made on tines mounted in individual rows on the shaft. The height and cross-section measurements were carried out using an electronic caliper MAUa-E2 (Optimum Vis, Poland) with a resolution of $\pm 0.01 \mathrm{~mm}$ at three points of the tine cross section: lower $\mathrm{A}-$ at the end of the tine, middle $\mathrm{B}$, upper $\mathrm{C}$.

In the next stage volumetric wear was determined using a direct immersion of tines in water (Fig. 2 ). The buoyant force of the immersed tine was measured in a measuring vessel set to an electronic scale WPS 600/C (Radwag, Poland) in the measuring range of $0.6 \mathrm{~kg}$, with an accuracy of $\pm 0.01 \mathrm{~g}$ in three repetitions.

Volumetric wear was determined from the difference in the nominal volume of weight of the immersed tine and the mean values of the buoyant forces. To determine the mass wear of individual tines, the same density of steel was assumed for all cases equal to $7.8 \mathrm{~g} \cdot \mathrm{cm}^{-3}$. The percentage wear was 
defined as a ratio of the volume of the worn part of the tine to the volume of the new tine determined from the real dimensions of the tine cross-sections and its length.

a)

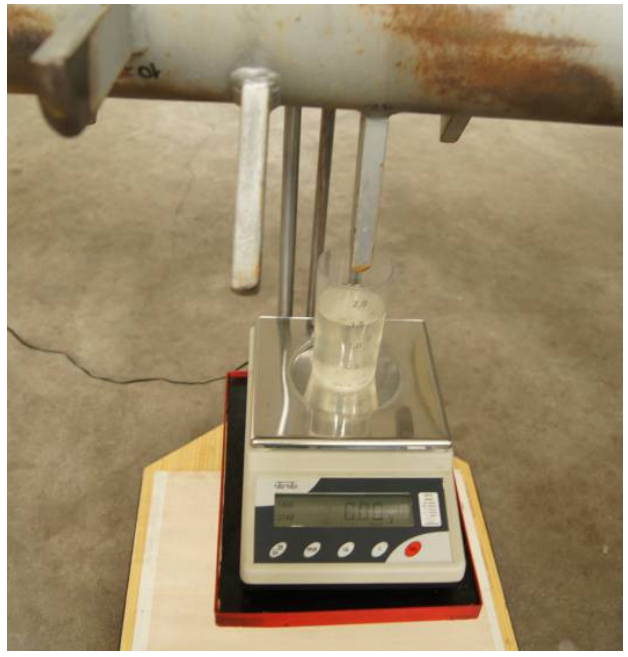

b)

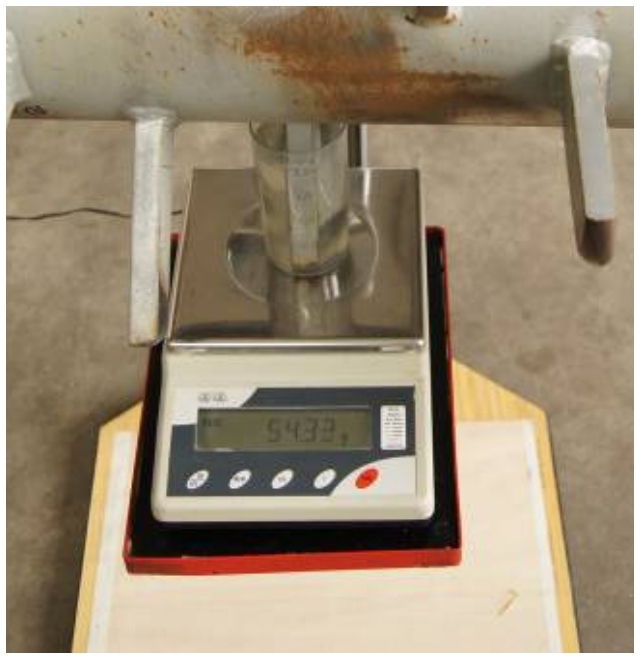

Fig. 2. Position of measuring vessel, laboratory scale and tine:

a) before the measurement, b) during the measurement

\section{Results and discussion}

During the work, the surfaces of rake tines affect the soil and are subjected to impacts against solids, stones and strong friction, which create areas of high stress on the front and top surfaces and their edges. As a result of this phenomenon, the blades are under a pulse load and are exposed to high abrasion and wear (Fig. 3).

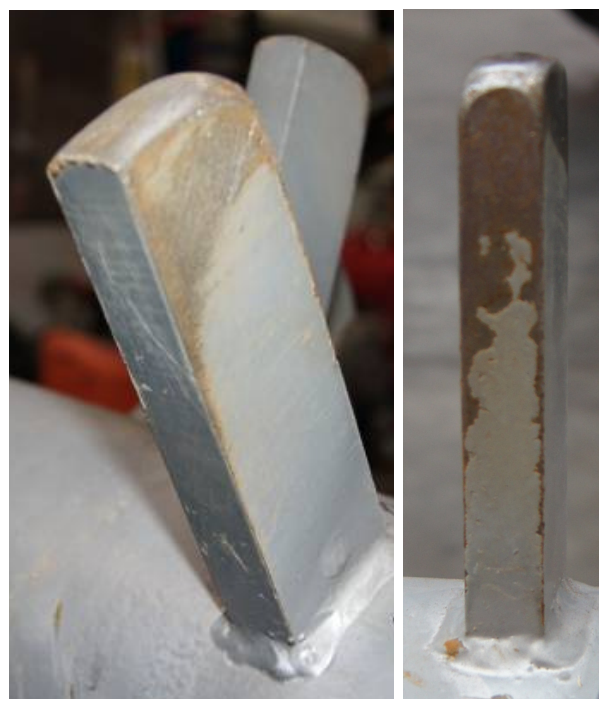

Fig. 3. View of wear of tine at rake shaft

Table 1 presents the results of measurements of worn tines. The largest loss of material occurred in the lower (working) zone. The fastest wear was observed on the top surface. Its abrasion was caused by friction against the bottom of the furrow.

At this point, the greatest friction force occurred, which led to "flowing" the material and formation of "lip" on the edge opposite to the tine's forehead. As a result, the length of the tine was shortened. In the central zone, only a few cases noticed a slight reduction in the thickness of the tine, which means that there was no noticeable wear on the side surfaces.

No wear was found in the upper zone, which is confirmed by observations. In the central zone, the effects of wear were visible on the frontal surface ("attack surface") of the tine. In the upper tine zone (cross-section C), slight signs of wear on several tines were observed. 
Dimensions of worn tines

Table 1

\begin{tabular}{|c|c|c|c|c|c|c|c|}
\hline \multirow{2}{*}{$\begin{array}{c}\text { Number } \\
\text { of tine }\end{array}$} & Material & $\begin{array}{c}\text { Tine } \\
\text { thickness, } \\
\text { mm }\end{array}$ & $\begin{array}{c}\text { Tine } \\
\text { width, } \\
\text { mm }\end{array}$ & $\begin{array}{c}\text { Tine } \\
\text { thickness, } \\
\text { mm }\end{array}$ & $\begin{array}{c}\text { Tine } \\
\text { width, } \\
\text { mm }\end{array}$ & $\begin{array}{c}\text { Tine } \\
\text { thickness, } \\
\text { mm }\end{array}$ & $\begin{array}{c}\text { Tine } \\
\text { width, } \\
\text { mm }\end{array}$ \\
\hline 1 & Hardox steel & 20.47 & 40.29 & 20.62 & 40.45 & 20.70 & 40.86 \\
\hline 2 & Hadfield steel & 20.57 & 40.40 & 20.66 & 40.62 & 20.78 & 40.92 \\
\hline 3 & boron steel & 20.10 & 40.60 & 20.38 & 40.71 & 20.51 & 40.98 \\
\hline 4 & Hardox steel & 21.09 & 39.45 & 21.20 & 40.54 & 21.27 & 41.00 \\
\hline 5 & Hadfield steel & 20.43 & 40.03 & 20.70 & 40.46 & 20.70 & 40.60 \\
\hline 6 & boron steel & 20.09 & 40.32 & 20.18 & 40.43 & 20.28 & 40.78 \\
\hline 7 & Hardox steel & 20.47 & 40.28 & 20.67 & 40.37 & 20.72 & 41.11 \\
\hline 8 & Hadfield steel & 20.33 & 40.02 & 20.55 & 40.59 & 20.76 & 40.79 \\
\hline 9 & boron steel & 19.99 & 40.06 & 20.24 & 40.74 & 20.36 & 40.96 \\
\hline 10 & boron steel & 15.77 & 40.03 & 15.98 & 40.48 & 15.99 & 40.41 \\
\hline 11 & boron steel & 15.62 & 39.76 & 15.84 & 40.23 & 16.03 & 40.47 \\
\hline 12 & boron steel & 15.52 & 39.85 & 15.95 & 40.21 & 15.14 & 40.64 \\
\hline 13 & boron steel & 15.58 & 39.51 & 15.93 & 40.00 & 16.25 & 40.16 \\
\hline 14 & boron steel & 15.82 & 40.03 & 16.19 & 40.34 & 16.43 & 40.47 \\
\hline 15 & boron steel & 15.79 & 40.34 & 16.23 & 40.55 & 16.37 & 40.84 \\
\hline 16 & boron steel & 16.11 & 40.20 & 16.30 & 40.45 & 16.64 & 40.50 \\
\hline 17 & boron steel & 15.93 & 40.32 & 16.20 & 40.64 & 16.38 & 40.86 \\
\hline 18 & boron steel & 15.77 & 40.23 & 16.30 & 40.58 & 16.34 & 40.89 \\
\hline 19 & boron steel & 15.86 & 39.89 & 15.95 & 40.22 & 16.14 & 40.49 \\
\hline 20 & boron steel & 15.91 & 40.28 & 16.20 & 40.73 & 16.31 & 40.80 \\
\hline 21 & boron steel & 15.92 & 40.24 & 16.22 & 40.54 & 16.68 & 41.22 \\
\hline 22 & boron steel & 15.71 & 40.54 & 16.02 & 40.64 & 16.34 & 40.88 \\
\hline 23 & boron steel & 15.99 & 40.27 & 16.25 & 40.73 & 16.38 & 40.82 \\
\hline 24 & boron steel & 15.94 & 40.32 & 16.12 & 41.10 & 16.28 & 41.38 \\
\hline & & & & & & & \\
\hline
\end{tabular}

Table 2 presents the results of volumetric, percentage and mass wear, and mass wear indicator of individual rotor tines. The linear relationship between the degree of mass wear $(y)$ of tines made of boron steel and the place of their welding to the shaft $(\mathrm{x})$ was investigated. To determine the strength of dependence between the location of the tines on the shaft and their wear, the Pearson's linear correlation coefficient was determined [11], in accordance to the formula (1):

$$
r_{x y}=\frac{\sum_{j=1}^{n}\left(x_{j}-\bar{x}\right)\left(y_{j}-\bar{y}\right)}{\sqrt{\left[\sum_{j=1}^{n}\left(x_{j}-\bar{x}\right)^{2} \sum_{j=1}^{n}\left(y_{j}-\bar{y}\right)^{2}\right.}} .
$$

For the assumed degree of significance $\alpha=0.05$ and the number of degrees of freedom 13, the limiting value of the correlation coefficient $r$-Pearson $=0.51$. The obtained value is equal to 0.81 and is greater than the value of the coefficient for the assumed level of significance, which means a statistically significant correlation. The strength of correlation in the range of 0.7-0.9 indicates a high linear relationship between the location of tines on the shaft and their wear.

The research results show that the tines wear increases proportionally towards the inner edge of the shaft according to the linear regression equation (Fig. 4) at $95 \%$ of confidence level. Because tine 
wear increases along the shaft, the cross-section of the tines on the final shaft section was increased and for testing these tines were made of various steel types. The highest average wear in the longer period of use was characterized by tines made of Hardox steel and it was $158 \mathrm{mg} \cdot \mathrm{km}^{-1}$, and the differences in the wear of tines made of Hadfield and boron steel were insignificant and were 131 $\mathrm{mg} \cdot \mathrm{km}^{-1}$ and $130 \mathrm{mg} \cdot \mathrm{km}^{-1}$, respectively (Tab. 3).

Table 2

Volumetric, percentage, mass wear and mass wear indicator

\begin{tabular}{|c|c|c|c|c|c|}
\hline $\begin{array}{l}\text { Number } \\
\text { of tine }\end{array}$ & $\begin{array}{l}\text { Volumetric } \\
\text { wear, } \mathrm{cm}^{3}\end{array}$ & $\begin{array}{l}\text { Percentage } \\
\text { wear, \% }\end{array}$ & $\begin{array}{c}\text { Mass wear, } \\
\text { g }\end{array}$ & $\begin{array}{c}\text { Mass wear } \\
\text { indicator, } \\
\mathbf{m g} \cdot \mathbf{k m}^{-1}\end{array}$ & Steel \\
\hline 1 & 8.74 & 8.40 & 68.20 & 184 & Hardox \\
\hline 2 & 5.58 & 5.37 & 43.59 & 117 & Hadfield \\
\hline 3 & 6.35 & 6.10 & 49.56 & 133 & boron \\
\hline 4 & 6.46 & 6.21 & 50.41 & 136 & Hardox \\
\hline 5 & 6.75 & 6.49 & 52.66 & 142 & Hadfield \\
\hline 6 & 7.29 & 7.01 & 56.93 & 153 & boron \\
\hline 7 & 8.24 & 7.93 & 64.34 & 173 & Hardox \\
\hline 8 & 7.91 & 7.60 & 61.72 & 166 & Hadfield \\
\hline 9 & 7.18 & 6.91 & 56.07 & 151 & boron \\
\hline 10 & 8.20 & 9.85 & 63.96 & 172 & boron \\
\hline 11 & 9.26 & 11.10 & 72.24 & 195 & boron \\
\hline 12 & 8.91 & 10.71 & 69.54 & 187 & boron \\
\hline 13 & 8.65 & 10.40 & 67.52 & 182 & boron \\
\hline 14 & 8.00 & 9.62 & 62.45 & 168 & boron \\
\hline 15 & 7.88 & 9.48 & 60.52 & 171 & boron \\
\hline 16 & 7.61 & 9.14 & 59.37 & 160 & boron \\
\hline 17 & 7.69 & 9.25 & 60.04 & 162 & boron \\
\hline 18 & 7.18 & 8.62 & 56.00 & 151 & boron \\
\hline 19 & 8.59 & 10.32 & 67.00 & 181 & boron \\
\hline 20 & 6.77 & 8.14 & 52.85 & 142 & boron \\
\hline 21 & 6.40 & 7.69 & 49.92 & 134 & boron \\
\hline 22 & 7.50 & 9.02 & 58.55 & 158 & boron \\
\hline 23 & 6.84 & 8.22 & 53.37 & 144 & boron \\
\hline 24 & 6.02 & 7.24 & 47.02 & 127 & boron \\
\hline
\end{tabular}

This may indicate that the Hardox steel tines had the hardest surface. However, along with the abrasion of the surface layer, a much faster material wear occurred in the longer period of operation of the rotor than in the case of other steel types. Tines made of Hardox steel were also characterized by the highest unevenness of wear. Deviations in tines wear from the mean value after the second stage did not exceed $18.4 \%$ for Hardox steel, $16 \%$ for Hadfield steel and $13 \%$ for boron steel.

Table 3

Average tines wear made of various types of steel

\begin{tabular}{|c|c|c|c|c|c|c|c|c|}
\hline \multirow{2}{*}{ Steel } & \multicolumn{2}{|c|}{$\begin{array}{c}\text { Volumetric wear, } \\
\mathrm{cm}^{3}\end{array}$} & \multicolumn{2}{|c|}{$\begin{array}{c}\text { Percentage wear, } \\
\%\end{array}$} & \multicolumn{2}{|c|}{ Mass wear, $\mathrm{g}$} & \multicolumn{2}{|c|}{$\begin{array}{c}\text { Mass wear } \\
\text { indicator, } \mathbf{m g} \cdot \mathbf{~ k m}^{-1}\end{array}$} \\
\hline & I stage & II stage & I stage & II stage & I stage & II stage & I stage & II stage \\
\hline Hardox & 0.95 & 7.49 & 0.92 & 7.25 & 7.42 & 58.45 & 44 & 158 \\
\hline Hadfield & 1.42 & 6.22 & 1.37 & 6.01 & 11.07 & 48.53 & 65 & 131 \\
\hline boron & 1.52 & 6.16 & 1.46 & 5.94 & 11.85 & 48.07 & 70 & 130 \\
\hline boron* & 1.86 & 7.23 & 2.24 & 8.70 & 14.55 & 56.38 & 86 & 152 \\
\hline
\end{tabular}

* tines with a smaller cross-section 


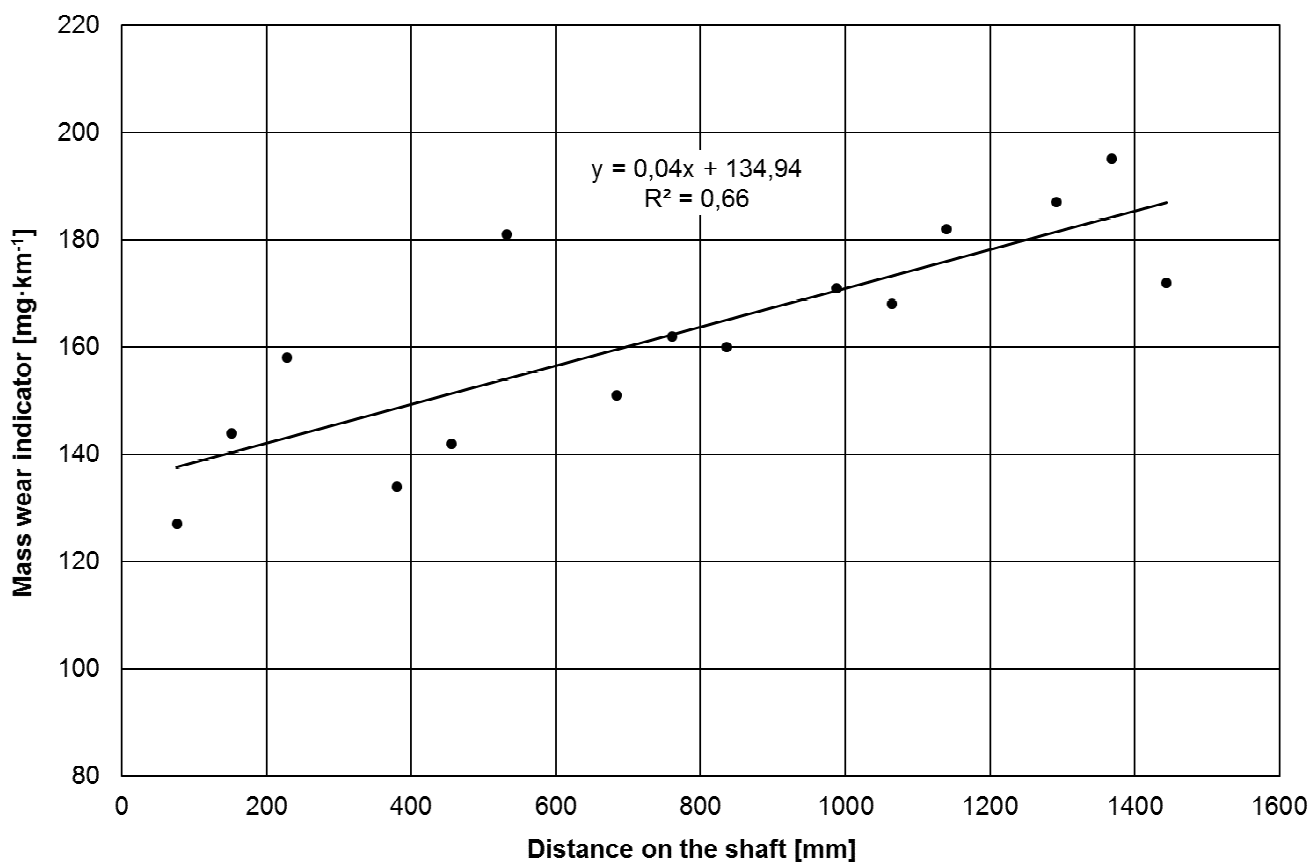

Fig. 4. Influence of tines position $(x)$ on rake shaft on mass wear indicator $(y)$

The results of durability and wear tests of ploughshares made of different steels with boron presented by Konstencki [12] indicate a comparable resistance to abrasive wear covered by material tests. Research in natural soil conditions of modern structural materials made of boron steel, abrasion resistant steel, multicomponent padding weld and tungsten carbide has shown that wear intensities increase linearly with the friction path [13]. The use of these materials significantly increases wear resistance in relation to commonly used steels for elements of machines working in the soil. Many authors indicate that the tool material loss can be observed and can be as much as $10 \mathrm{~g}$ per kilometer of tilling.

Tines with smaller cross-sections ( $16 \mathrm{~mm}$ thick), made of the same boron steel, were worn more intensely than the tines with a larger thickness $(20 \mathrm{~mm})$, and the average values of the indicators amounted to $152 \mathrm{mg} \cdot \mathrm{km}^{-1}$ and $130 \mathrm{mg} \cdot \mathrm{km}^{-1}$, respectively (Fig. 5).

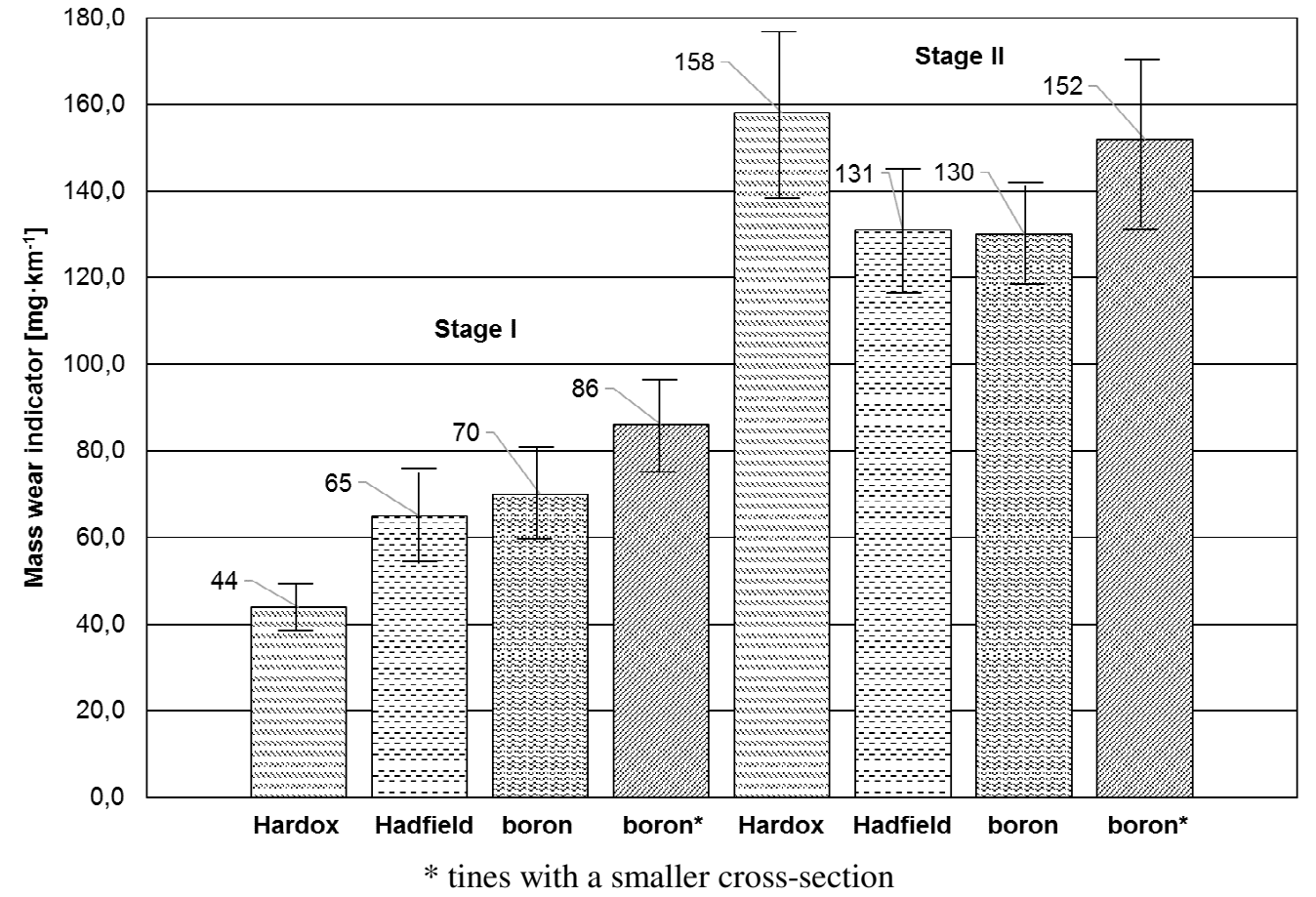

Fig. 5. Tines wear indicator from different types of steel in the first and second stages 
A study conducted by Tugrul and Icoz [14] found the wear of ploughshare, cultivator and harrows to be $150 \mathrm{~g} \cdot \mathrm{ha}^{-1}, 135 \mathrm{~g} \cdot \mathrm{ha}^{-1}$ and $90 \mathrm{~g} \cdot \mathrm{ha}^{-1}$, respectively. According to Bayhan [15], the wear of the ploughshares is an average of 90 to $210 \mathrm{~g} \cdot \mathrm{ha}^{-1}$. This indicates that among these tillage tools the ploughshare experiences the most abrasive wear in soils. For rotary tiller blades, the authors [16] indicate wear of 78 and $158 \mathrm{~g}$ after 45 ha cultivated depending on the type of the tiller blades. In our research, the tines wear was $15.24 \mathrm{~g} \cdot \mathrm{ha}^{-1}$.

\section{Conclusions}

1. The tines wear depends on the place of fixing on the rake shaft and increases linearly in the direction of the stones moving towards the machine throat.

2. The highest unevenness of wear during operation was characterized by the tines made of Hardox steel.

3. Tines made of the same boron steel of smaller cross-sections (thickness of $16 \mathrm{~mm}$ ) were worn more intensely than the tines of a higher thickness $(20 \mathrm{~mm})$.

4. Considering the degree of tines wear, the most favorable solution is to use tines made of Hadfield or boron steel with a thickness of $20 \mathrm{~mm}$.

5. A more detailed assessment of wear of individual tine surfaces can be carried out using 3D scanning and image processing.

\section{References}

[1] Kostencki P. Badanie intensywności zużycia wybranych stali na elementy robocze pracujące w glebie. (Investigation of some chosen steels used for soil working elements). Tribologia 2-2011, pp. 33-46 (In Polish).

[2] Miller A.E. Wear in Tillage Tools, Wear Control Handbook, Peterson, M.B., and Winer, W.O., eds., ASME New York 1980, pp. 987-998.

[3] Mitrus J. Technologia usuwania kamieni z pól. (Technology for removing stones from fields). IBMER Warszawa: 20, 1985 (In Polish).

[4] Pirowski Z., Olszyński J., Turzyński J., Gościański M. Elementy maszyn rolniczych pracujących w glebie wykonane z nowoczesnych tworzyw odlewniczych. (Elements of agricultural machines working in the ground made of modern casting materials). Motrol, 2006, 8, 169-180 (In Polish).

[5] Rutkowski P., Stobierski L. Ewolucja mikrostruktury tworzyw kompozytowych z węglików metali przejściowych. (Microstructure evolution of composite materials based on transition metal carbides). Materiały Ceramiczne 61(2). 2009, pp. 140-145. (In Polish).

[6] Pertek-Owsianna A., Kapcińska-Popowska D., Bartkowska A., Wiśniewska K. Analiza mikrostruktury i właściwości warstw wierzchnich otrzymanych w wyniku borowania dyfuzyjnego i laserowego stali z mikrododatkiem boru. (Analysis of microstructure and properties of the surface layer obtained of results diffusion and laser boriding of steel with microaddition of boron). Inżynieria Materiałowa 5 (207), 2015, pp. 256-259 (In Polish).

[7] Bolanowski K. Wear of working elements made of Hadfield cast steel under industrial conditions. Problemy Eksploatacji (Maintenance Problems), Zeszyty Naukowe, Instytut Technologii Eksploatacji 2/2008 (69), Radom 2008, pp. 25-32.

[8] Talarczyk W. Zużycie elementów roboczych maszyn w procesie uprawy gleby. (The wear of machine working elements in the soil cultivation process). Prace Przemysłowego Instytutu Maszyn Rolniczych, no 2, 1993, pp. 36-42. (In Polish).

[9] Kostencki P. Wskaźnik liniowy alternatywą dla masowego wskaźnika przy ocenie zużycia lemieszy płużnych. (The linear index as alternative of the mass index for evaluation of wear of ploughshares). Journal of Research and Applications in Agricultural Engineering 2008, Vol. 53(1), pp. 35-39. (In Polish).

[10] Bialobrzeska B., Kostencki P. Abrasive wear characteristics of selected low-alloy boron steels as measured in both field experiments and laboratory tests. Wear 328-329 (2015) pp. 149-159.

[11]Luszniewicz A., Słaby T., 2001: Statystyka. Teoria i zastosowania. (Statistics. Theory and applications). Wydawnictwo C.H. Beck, Warszawa: 499 (In Polish). 
[12] Kostencki P., Łętkowska B., Nowowiejski R. Polowe badania odporności na zużycie ścierne lemieszy płużnych wykonanych ze stali z dodatkiem boru. (Field tests of resistance to abrasive wear of ploughshares made of boron steel). Tribologia 3-2013, pp. 49-79 (In Polish).

[13] Napiórkowski J., Kołakowski K., Pergoł A. Ocena zużycia nowoczesnych materiałów konstrukcyjnych stosowanych na narzędzia obrabiające glebę. (Evaluation of the wear of modern construction materials used to produce soil treatment tools). Inżynieria Rolnicza 5(130) 2011 (In Polish).

[14] Tugrul K. M., Icoz E. Determination of Wear Characteristics of Drill Cultures of Precision Drilling Machine Made of Different Materials, Tarim Bilimleri Dergisi,11(4): 2005, pp. 428-433.

[15] Bayhan Y. Reduction of wear via hardfacing of chisel ploughshare. Tribology International, 39: 2006, pp. 570-574.

[16] Caslli Sh.,. Hasanaj A., Dimo Dh. Optimization of tribological parameters in the design of rotary tiller blades. Scientific proceedings v international scientific-technical conference "agricultural machinery" 2017, Bułgaria, Sofia, vol. 1, pp. 36-40. 